Article

\title{
Exogenous Application of Nitric Oxide Mitigates Water Stress and Reduces Natural Viral Disease Incidence of Tomato Plants Subjected to Deficit Irrigation
}

\author{
Amr Elkelish ${ }^{1}$ D, Mohamed F. M. Ibrahim ${ }^{2, * \mathbb{D}}$, Hatem Ashour ${ }^{2}$, Ahmed Bondok ${ }^{3}$ (D), Soumya Mukherjee ${ }^{4}(\mathbb{D}$, \\ Tariq Aftab ${ }^{5}$, Mohamed Hikal ${ }^{6}$, Ahmed Abou El-Yazied ${ }^{7}$ (D), Ehab Azab 8,9 ${ }^{(D}$, Adil A. Gobouri ${ }^{10}$, \\ Mohamed Moustafa-Farag ${ }^{11}$, Amr A. Metwally ${ }^{7}$ and Hany G. Abd El-Gawad 7,*iD
}

check for

updates

Citation: Elkelish, A.; Ibrahim, M.F.M.; Ashour, H.; Bondok, A.; Mukherjee, S.; Aftab, T.; Hikal, M.; El-Yazied, A.A.; Azab, E.; Gobouri, A.A.; et al. Exogenous Application of Nitric Oxide Mitigates Water Stress and Reduces Natural Viral Disease Incidence of Tomato Plants Subjected to Deficit Irrigation. Agronomy 2021, 11, 87. https://doi.org/10.3390/ agronomy11010087

Received: 1 December 2020 Accepted: 31 December 2020 Published: 5 January 2021

Publisher's Note: MDPI stays neutral with regard to jurisdictional clai$\mathrm{ms}$ in published maps and institutional affiliations.

Copyright: (C) 2021 by the authors. Licensee MDPI, Basel, Switzerland. This article is an open access article distributed under the terms and conditions of the Creative Commons Attribution (CC BY) license (https:// creativecommons.org/licenses/by/ $4.0 /)$.
1 Botany Department, Faculty of Science, Suez Canal University Ismailia, Ismailia 41522, Egypt; amr.elkelish@science.suez.edu.eg

2 Department of Agricultural Botany, Faculty of Agriculture, Ain Shams University, Cairo 11566, Egypt; Hatem_ashour@agr.asu.edu.eg

3 Department of Plant Pathology, Faculty of Agriculture, Ain Shams University, Cairo 11566, Egypt; ahmed_bondok@agr.asu.edu.eg

4 Department of Botany, Jangipur College, University of Kalyani, Kalyani 742213, India; soumobios@gmail.com

5 Department of Botany, Aligarh Muslim University, Aligarh 202002, India; tarik.alig@gmail.com

6 Department of Biochemistry, Faculty of Agriculture, Ain Shams University, Cairo 11566, Egypt; Mohamed_elsayed4@agr.asu.edu.eg

7 Department of Horticulture, Faculty of Agriculture, Ain Shams University, Cairo 11566, Egypt; ahmed_abdelhafez2@agr.asu.edu.eg (A.A.E.-Y.); amr_metwally@agr.asu.edu.eg (A.A.M.)

8 Department of Biotechnology, College of Science, Taif University, P.O. Box 11099, Taif 21944, Saudi Arabia; e.azab@tu.edu.sa

9 Botany and Microbiology Department, Faculty of Science, Zagazig University, Zagazig 44519, Egypt

10 Department of Chemistry, College of Science, Taif University, P.O. Box 11099, Taif 21944, Saudi Arabia; a.gobouri@tu.edu.sa

11 Horticulture Research Institute, Agriculture Research Center, 9 Gmaa St, Giza 12619, Egypt; m_m_kamel2005@yahoo.com

* Correspondence: Ibrahim_mfm@agr.asu.edu.eg (M.F.M.I.); hany_gamal2005@agr.asu.edu.eg (H.G.A.E.-G.); Tel.: +20-1123403173 (M.F.M.I.)

Abstract: The present work reveals the beneficial role of sodium nitroprusside (SNP; NO donor concentration: 50 and $100 \mu \mathrm{M}$ ) in mitigation of water stress accompanied by a reduction in viral disease incidence in tomato plants subjected to deficit irrigation. The plants were grown under two irrigation regimes: well-watered (WW; irrigated after the depletion of 55-60\% of available soil water) and water deficit (WD; irrigated after the depletion of $85-90 \%$ of available soil water) in two seasons of 2018 and 2019. The results indicated that under water stress conditions, plant growth, chlorophyll, relative water content (RWC), and fruit yield were decreased. Conversely, water stress significantly increased the MDA, proline, soluble sugars, and antioxidant enzymes' activities. Moreover, it was obvious a negligible increase in the fruit content from $\mathrm{NO}_{2}$ and $\mathrm{NO}_{3}$. Water-deficit stress, however, had a positive impact on reducing the percentage of viral disease (TMV and TYLCV) incidence on tomato plants. Similarly, SNP application in the form of foliar spray significantly reduced the disease incidence, the severity, and the relative concentrations of TMV and TYLCV in tomato plants raised under both WW and WD conditions. The treatment of SNP at $100 \mu \mathrm{M}$ achieved better results and could be recommended to induce tomato plant tolerance to water stress. Thus, the present work highlights the role of NO (SNP) in the alleviation of water stress in tomato plants and subsequent reduction in viral disease incidence during deficit irrigation.

Keywords: Solanum lycopersicum L.; sodium nitroprusside; drought stress; antioxidant enzymes; nitrite; nitrate; viral disease; yield 


\section{Introduction}

Tomato (Solanum lycopersicum L.) is one of the world's most popular vegetable crops. It contains considerable amounts of minerals, amino acids, vitamins, sugars, and antioxidants [1]. It has been found that the tomato plant is susceptible to drought stress at the early stages of its life cycle [2]. Conversely, short periods of water deficit (WD) at the flowering or fruit set stages may have significant benefits to yield tomato fruits with high standards of quality but adversely reduce the total yield quantitatively [3]. The extent of the injurious effect of drought depends on the severity and duration of stressed periods [4], while viral infections seriously affect the growth and yield of tomato plants by modifying many physiological and biochemical aspects $[5,6]$.

WD may trigger a broad spectrum of adverse effects that can restrict plant growth and development through the inhibition of cell division [7], photosynthesis [8], and disequilibrium of plant growth regulators [9]. Plant responses to water stress are complex and comprise a cascade of interconnected signaling and perception systems in the presence of specific osmotic sensors such as phospholipases, kinases, Abscisic acid (ABA), Ca, Reactive oxygen species (ROS), and other secondary messengers [10,11]. Furthermore, WD can induce oxidative damages that may destroy lipid, protein, and nucleic acids [12].

Nitric oxide (NO) is a multifunctional signaling molecule and gaseous hormone that is ubiquitous in both the animal and plant kingdom. As one of the major reactive nitrogen species (RNS), NO plays a pivotal role in the relative balance between oxidative and nitrosative stresses [13,14]. Moreover, nitric oxide is involved in a wide array of complex biological effects including the stimulation of adventitious roots through mediating the indole acetic acid induction [15], regulation of plant growth, photosynthesis, antioxidant capacity, and ripening of both climacteric and nonclimacteric fruits [16-18]. Furthermore, it has been evidenced that $\mathrm{NO}$ can improve resistance to plant diseases by activating the expression of $P R$ genes, i.e., $P R 1$ and $P R 5$, and inducing endogenous salicylic acid (SA) [19]. Generally, exogenous NO has been reported to improve the tolerance of tomato plants to different adverse environmental conditions, e.g., heavy metals [18], drought [20], and salinity stress [21]. However, the interconversion (oxidoreductive steps) of nitrite and nitrate contents in water-stressed tomato fruits subjected to exogenous NO treatment needs further investigations for deciphering variabilities in fruit quality [18].

Not much information is available to substantiate the role of NO in regulating resistance to viral disease in tomato plants. In view of the lacunae in the investigation, the present investigations aimed at understanding the role of $\mathrm{NO}$ in mitigating the negative effects of WD and reducing the incidence of viral diseases under field conditions by comparing the growth, relative water content (RWC), biochemical constituents, antioxidant enzymes, viral diseases incidence, viral diseases severity index, and the relative concentrations of virus particles by biological and serological methods.

\section{Materials and Methods}

\subsection{Plant Materials and Growth Conditions}

Two field experiments were conducted in two successive seasons of 2018 and 2019 from 1 September to 30 December of each season. Five-week-old tomato transplants (Cheyenne E448 produced by Syngenta Egypt) were set up into the experimental soil at the Experimental Farm, Faculty of Agriculture, Ain Shams University, Shoubra ElKheima, Cairo, Egypt. The chemical and physical properties of the experimental soil were determined as precultivation in each season (Table 1). Monthly averages of climatic data surrounding the plants in the experimental site are supported in Table 2. During the soil preparation, organic manure at $48 \mathrm{~m}^{3} /$ ha and calcium superphosphate $\left(15 \% \mathrm{P}_{2} \mathrm{O}_{5}\right)$ at $770 \mathrm{~kg} / \mathrm{ha}$ were distributed. 
Table 1. Chemical and physical properties of the experimental soil.

\begin{tabular}{|c|c|c|c|c|c|c|c|c|}
\hline \multirow{2}{*}{ Season } & \multicolumn{4}{|c|}{ Macroelements (\%) } & \multirow{2}{*}{$\mathrm{pH}$} & \multicolumn{3}{|c|}{ Microelements (ppm) } \\
\hline & $\mathbf{N}$ & $\mathbf{P}$ & & & & $\mathrm{Fe}$ & B & Zn \\
\hline 2018 & 0.28 & 0.43 & & & 8.20 & 1.98 & 3.90 & 2.97 \\
\hline \multirow[t]{3}{*}{2019} & 0.20 & 0.31 & & & 7.88 & 2.54 & 4.05 & 2.76 \\
\hline & \multirow{2}{*}{$\mathrm{CaCO}_{3}(\%)$} & \multirow{2}{*}{$\mathrm{EC}\left(\mathrm{dS} \mathrm{m}^{-1}\right)$} & \multicolumn{3}{|c|}{ Soluble anions (meq $\mathrm{L}^{-1}$ ) } & \multicolumn{3}{|c|}{ Soluble cations (meq $\mathrm{L}^{-1}$ ) } \\
\hline & & & $\mathrm{HCO}_{3}{ }^{-}$ & $\mathrm{SO}_{4}^{-}$ & $\mathrm{Cl}^{-}$ & $\mathrm{Ca}^{++}$ & $\mathrm{Mg}^{++}$ & $\mathrm{Na}^{+}$ \\
\hline 2018 & 1.43 & 0.98 & 2.86 & 2.40 & 3.20 & 5.04 & 3.55 & 2.72 \\
\hline 2019 & 1.28 & 0.84 & 3.20 & 3.28 & 3.66 & 4.83 & 2.70 & 3.23 \\
\hline \multirow{2}{*}{\multicolumn{2}{|c|}{ Soil }} & \multicolumn{2}{|c|}{ Sand (\%) } & Silte $(\%)$ & \multicolumn{2}{|c|}{ Clay $(\%)$} & \multicolumn{2}{|c|}{ Soil texture } \\
\hline & & \multicolumn{2}{|c|}{22.56} & 41.21 & \multicolumn{2}{|c|}{36.23} & \multicolumn{2}{|c|}{ Clay loam } \\
\hline
\end{tabular}

Table 2. Monthly averages of the climatic data in the experimental site during the seasons of 2018 and 2019.

\begin{tabular}{|c|c|c|c|c|c|c|}
\hline & $\begin{array}{c}\text { Temperature } \\
\text { Average } \\
\left({ }^{\circ} \mathrm{C}\right)\end{array}$ & $\begin{array}{c}\text { Maximum } \\
\text { Temperature } \\
\left({ }^{\circ} \mathrm{C}\right)\end{array}$ & $\begin{array}{c}\text { Minimum } \\
\text { Temperature } \\
\left({ }^{\circ} \mathrm{C}\right)\end{array}$ & $\begin{array}{l}\text { Relative } \\
\text { Humidity } \\
(\%)\end{array}$ & $\begin{array}{c}\text { Solar } \\
\text { Radiation } \\
\left(\mathrm{MJ} \mathrm{m}^{-2} \text { day }^{-1}\right)\end{array}$ & $\begin{array}{c}\text { Precipitation } \\
\text { Sum } \\
\left(\mathrm{mm} \mathrm{day}^{-1}\right)\end{array}$ \\
\hline \multicolumn{7}{|c|}{2018} \\
\hline September & 28.1 & 36.3 & 21 & 47.1 & 22.68 & 0 \\
\hline October & 24.1 & 31.7 & 18.1 & 50.8 & 18.17 & 4.82 \\
\hline November & 19.5 & 26.5 & 14.2 & 55.9 & 10.1 & 6.17 \\
\hline December & 14.3 & 20.5 & 9.7 & 63.3 & 10.89 & 9.15 \\
\hline \multicolumn{7}{|c|}{2019} \\
\hline September & 27.6 & 36 & 20.7 & 47.56 & 18.86 & 0 \\
\hline October & 24.8 & 32.5 & 18.7 & 53.52 & 17.78 & 16.82 \\
\hline November & 20.7 & 28.5 & 14.9 & 51.79 & 14.39 & 0.11 \\
\hline December & 14.4 & 21 & 9.6 & 63.7 & 11.46 & 25.9 \\
\hline
\end{tabular}

\subsection{Experimental Design}

In this study, two levels of irrigation regimes separated by an alley ( $2 \mathrm{~m}$ wide) as a border between them were implemented in this study. The first level represents the well-watered (WW) plants, while the second level represents the water-stressed plants. The treatments of irrigation were started 10 days after transplanting ( 0 time): at the first level, irrigation was resumed after the depletion of $55-60 \%$ of available soil water (WW), whereas, in the second level, irrigation was resumed after the depletion of $85-90 \%$ of available soil water (WD). Irrigation scheduling was applied according to the soil water status known as the field capacity (FC). During precultivation in the beginning of each season, soil samples were taken by an Auger T-Handle at depths of $0-20$ and 20-40 cm from the soil surface to determine the field capacity, wilting point (WP), and soil available water (SAW) in the laboratory of soil sciences, as shown in Table 3. The exact timing of next irrigation was determined by the regular estimation of the soil moisture content. The samples were dried at $105^{\circ} \mathrm{C}(24 \mathrm{~h})$ and weighed until constant weight. The percentage of soil moisture was measured using the following equation:

Soil moisture $(\%)=[($ weight before drying - weight after drying $) /$ weight after drying $] \times 100 \%$.

Sodium nitroprusside (SNP) at two levels (i.e., 50 and $100 \mu \mathrm{M}$ ) produced by S D Fine Chem Limited (SDFCL; Maharashtra, India) was used as a donor for nitric oxide (NO). Plants were regularly sprayed three times at 1,5 , and 9 weeks after transplanting (WAT), (quantity: $560 \mathrm{~mL} / \mathrm{plot}$ ). The experimentation was a split-plot design with three replicates. The treatments were assigned in the main plots, and then SNP was spread equally between subplots. 
Table 3. Field capacity (FC), wilting point, and available soil water of the experimental soil in the two seasons of 2018 and 2019.

\begin{tabular}{ccccccc}
\hline \multirow{2}{*}{$\begin{array}{c}\text { Depth of } \\
\text { Soil }(\mathbf{c m})\end{array}$} & FC (\%) & Wilting Percentage & Available Water (\%) & FC (\%) & Wilting Percentage & Available Water (\%) \\
\cline { 2 - 7 } & 23.42 & 13.67 & 9.75 & 22.82 & 12.93 & 9.89 \\
$0-20$ & 12.43 & 10.32 & 22.61 & 12.88 & 9.73 \\
\hline Average & 23.09 & 13.05 & 10.04 & 22.72 & 12.91 & 9.81 \\
\hline
\end{tabular}

\subsection{Data Recorded}

\subsubsection{Vegetative Growth, Chlorophyll Content, and RWC}

Four plants from each experimental unit at 70 days after transplanting (10 WAT) at the beginning of flowering were used to measure the phenotypic characters. Shoot fresh weight was immediately determined using a digital balance. The samples were cleaned by tap water and then dried in an air-vacuum oven to constant weight. Another four plants from each experimental unit were used to determine the biochemical constituents of leaves (the 4th compound leaf from the top). Chlorophyll was estimated in accordance of the equation of Arnon [22]. The leaf RWC was measured following the method of Ünyayar, et al. [23].

\subsubsection{Proline, Soluble Sugars, and Lipid Peroxidation}

Lipid peroxidation was determined as described by Heath and Packer [24]. Proline was determined according to the method developed by Bates, et al. [25]. Total soluble sugars were assessed by the method of Chow and Landhäusser [26].

2.3.3. Enzyme Assays (Ascorbate Peroxidase (APX), Catalase (CAT), and Peroxidase (POX) Activities)

Total soluble protein was determined according to Bradford [27]. APX (EC 1.11.1.11) activity was measured according to the method of Nakano and Asada [28]. The rate of ascorbate oxidation was calculated using the extinction coefficient $\left(\varepsilon=2.8 \mathrm{mM}^{-1} \mathrm{~cm}^{-1}\right)$. CAT (EC 1.11.1.6) activity was determined according to the method of Cakmak, et al. [29]. Peroxidase (EC 1.11.1.7) activity was quantified by the method of Hammerschmidt, et al. [30].

\subsubsection{Disease Incidence and Severity (TMV and TYLCV)}

Disease incidence was determined based on the symptoms of diseased plants.

The amount of diseased plants was assessed by:

$$
\mathrm{IC}=n / \mathrm{N} \times 100,
$$

where IC is the disease incidence; $n$ is the number of diseased plants; $\mathrm{N}$ is the total number of plants assessed.

The damage caused by diseases was quantified by the severity index of the disease. A modified 0-5 scale from Nelson, et al. [31] based on disease symptoms was used to score the diseased plants as follows: 0 indicated no disease symptoms, and 5 represented the most severe leaf distortion.

Disease severity index was then measured for each treatment using the equation of Nelson, et al. [31].

\section{Relative Concentrations of TMV and TYLCV in the Infected Plants}

Relative concentrations of $T M V$ and $T Y L C V$ in the infected plants were determined at 6 and 10 WAT with two methods in the two seasons.

a. Serologically: Enzyme-linked immunosorbent assay [32] was used to determine $T S W V$ levels in sap of young leaves of infected tomato plants 30 days postinoculation (dpi). Absorbance values were determined using an ELISA reader (BIE \& BERNTSEN AS) at $405 \mathrm{~nm}$ for $1 \mathrm{~h}$. 
b. Biologically: the number of local lesions appeared after 7 dpi with $T M V$ from the grinded crud sap ( $1 \mathrm{~g}$ collected tomato leaves sample from each treatment with a phosphate buffer (pH: 7.4)) on Nicotiana glutinosa (N. glutinosa) plants.

\subsubsection{Fruit Yield and Lycopene, Nitrite, and Nitrate Contents}

Plants were selected randomly from each plot and labelled. Tomato fruits were taken from the labelled plants several times, and the average weight of the yield (unit: ha) was calculated. Lycopene content was assayed in accordance to Fish, et al. [33]. Nitrate and nitrite levels in the leaves were measured according to the method of Sen and Donaldson [34].

\subsection{Statistics}

All the biostatistics evaluation (means and one-way ANOVA) was done by SAS [35] software. The means of the three replicates were calculated, and the significant differences between the means were determined by Duncan's test. A linear regression analysis was also performed for certain parameters measured in this investigation.

\section{Results}

3.1. Exogenous SNP Partially Improves Shoot Fresh Weight and Modulates Pigment Content and Fruit Yield Attributes during Water Stress

Tomato plants subjected to deficit irrigation exhibited a significant $(p \leq 0.05)$ reduction in shoot fresh weight (Figure 1). In the present work, chlorophyll and lycopene contents exhibited an opposite trend in the presence and absence of the SNP treatment in tomato plants (Figures 1 and 2). Water stress triggered a significant decrease in total chlorophyll content in comparison with in the WW plants. The application of SNP (50 and $100 \mu \mathrm{M})$ triggered a partial increase in total chlorophyll content, which was, however, higher in well watered conditions (Figure 1). Generally, the leaf spraying with SNP exhibited more healthy growth with a significantly higher chlorophyll content in comparison to in the untreated plants in both seasons.

The fruit yield of tomato plants and its contents for lycopene, nitrite, and nitrate were evaluated under two irrigation regimes and different SNP treatments. Under the water stress conditions, the fruit yield was significantly $(p \leq 0.05)$ decreased compared to under the well-irrigated conditions in both seasons (Figure 2A). A similar trend was observed with respect to nitrite and nitrate contents (Figure 2C). The nitrite content was completely absent under the water stress conditions, while the nitrate content was reduced to lower values than in those under the well-irrigated conditions in both seasons. The nitrate content was significantly increased in the SNP-applied plants compared to in the untreated ones in both seasons. In contrast, lycopene was increased dramatically with the reduction of the irrigation level (average of the two seasons) (Figure 2B). The foliar application of SNP at $100 \mu \mathrm{M}$ caused a higher significant increase in the fruit yield in both seasons. On the other hand, the fruit maturity was delayed, and the lycopene content was significantly decreased with the SNP application. 


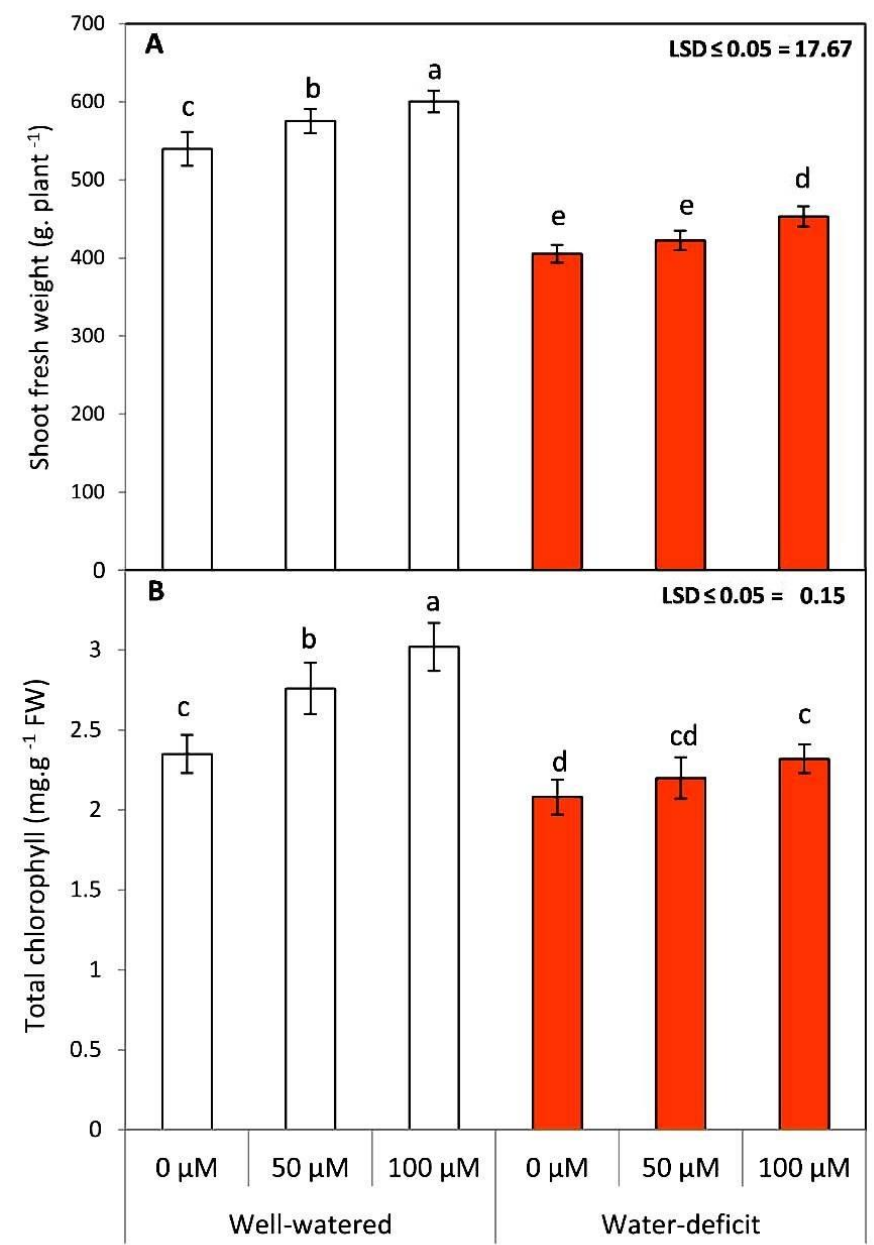

Figure 1. Effects of sodium nitroprusside (SNP) as foliar applications at 0,50 , and $100 \mu \mathrm{M}$ on shoot fresh weight and total chlorophyll of tomato plants grown under well-watered and water deficit irrigation. Data followed by the same letters are not significantly different using the LSD multiple rang test at a $5 \%$ level.
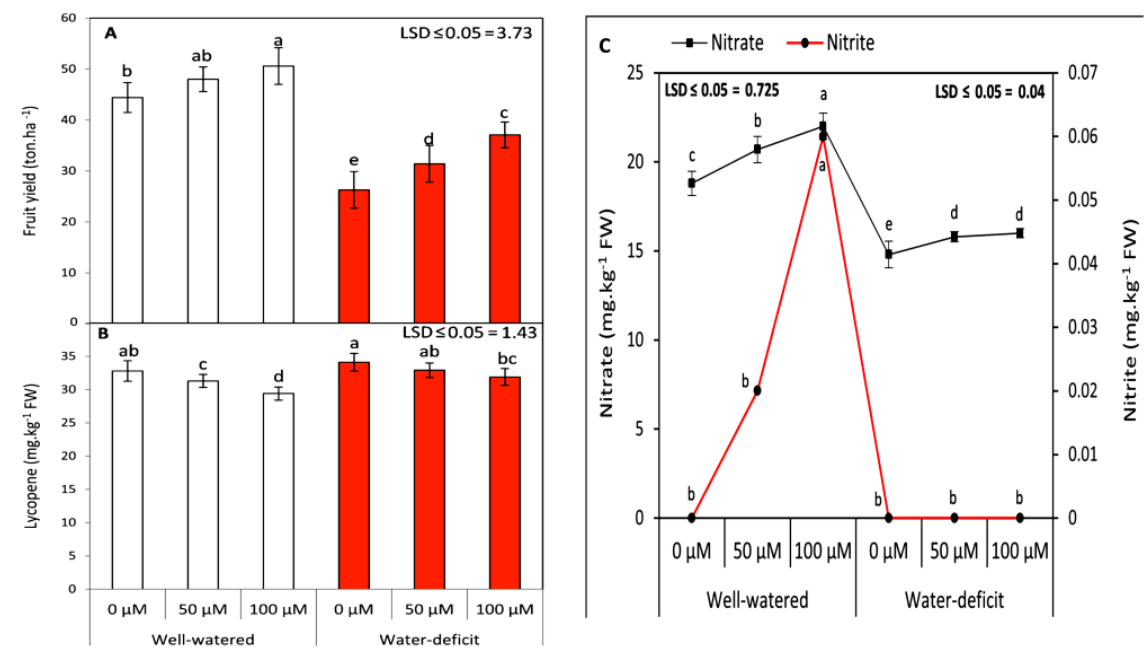

Figure 2. Effects of SNP as foliar applications at 0, 50, and $100 \mu \mathrm{M}$ on the fruit yield (A) and its contents of lycopene $(\mathbf{B})$ as well as nitrite and nitrate $(\mathbf{C})$ of tomato plants grown under well-watered and water deficit irrigation. Data followed by the same letters are not significantly different using the LSD multiple rang test at a $5 \%$ level. 
3.2. SNP Treatment Modulates RWC and Osmolyte Accumulation in Tomato Plants Subjected to Water Stress

The tomato plants subjected to WD exhibited a significant $(p \leq 0.05)$ decrease in RWC, which was, however, marginally increased in the presence of SNP treatment (Figure 3A). Proline and total soluble sugars exhibited a marked increase in their content during water stress (Figure 3B,C), thus indicating their role in osmotic adjustment. Interestingly, the application of SNP (50 and $100 \mu \mathrm{M}$ ) increased RWC and osmolyte accumulation under both the WW and WD conditions. These results indicated that exogenous SNP at an appropriate concentration could help tomato plants to resist the effect of deficit irrigation.

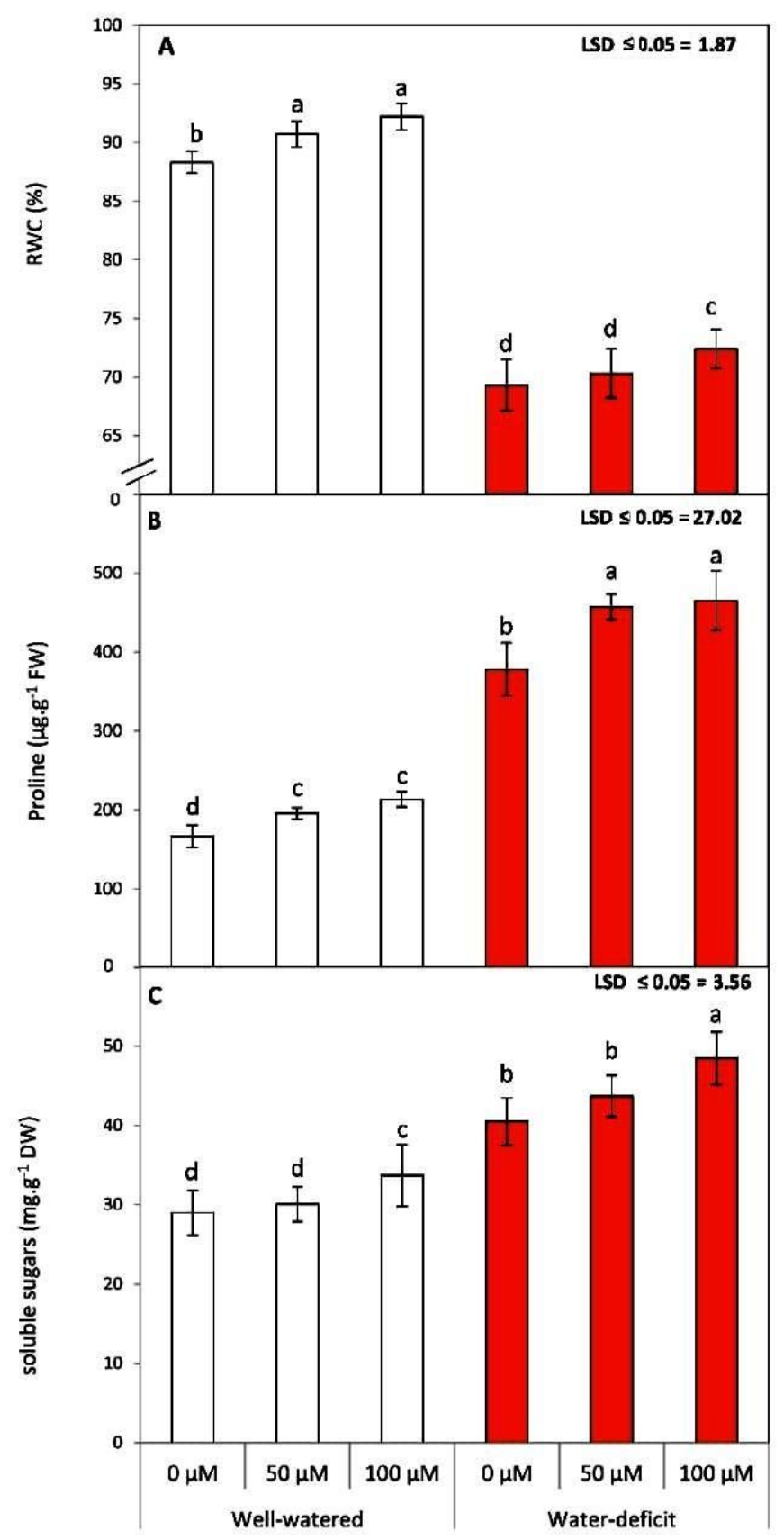

Figure 3. Effect of SNP as foliar applications at 0,50 , and $100 \mu \mathrm{M}$ on leaf's relative water content (RWC) (A), proline (B), and soluble sugars (C) of tomato plants grown under well-watered and water deficit irrigation. Data followed by the same letters are not significantly different using the LSD multiple rang test at a $5 \%$ level. 


\subsection{Exogenous SNP Reduces Lipid Peroxidation and Increases Enzymatic Antioxidative Defense} in Water-Stressed Tomato Plants

The exposure of tomato plants to deficit irrigation exhibited a conspicuous and significant $(p \leq 0.05)$ increase in lipid peroxidation (MDA content) when compared to under the well-irrigated plants in both seasons (Figure 4A). The application of SNP resulted in a decrease in MDA content in both WW and WD conditions, which was, however, more intense in the water-stressed plants subjected to $100 \mu \mathrm{M}$ SNP. The deficit irrigation significantly $(p \leq 0.05)$ increased the activities of antioxidant enzymes (Figure 4B-D; peroxidase: POD) when compared to under the WW conditions in both seasons. The foliar application of SNP further boosted the antioxidant defense system by increasing the activities of antioxidant enzymes. Generally, the highest significant results for all studied enzymes were obtained by the treatment of $100 \mu \mathrm{M}$ SNP compared to for the untreated plants in both seasons. These results suggested that the NO donor (SNP) is effective in the responses of tomato plants to water stress by reducing lipid peroxidation and by inducing enzymatic antioxidative defense.

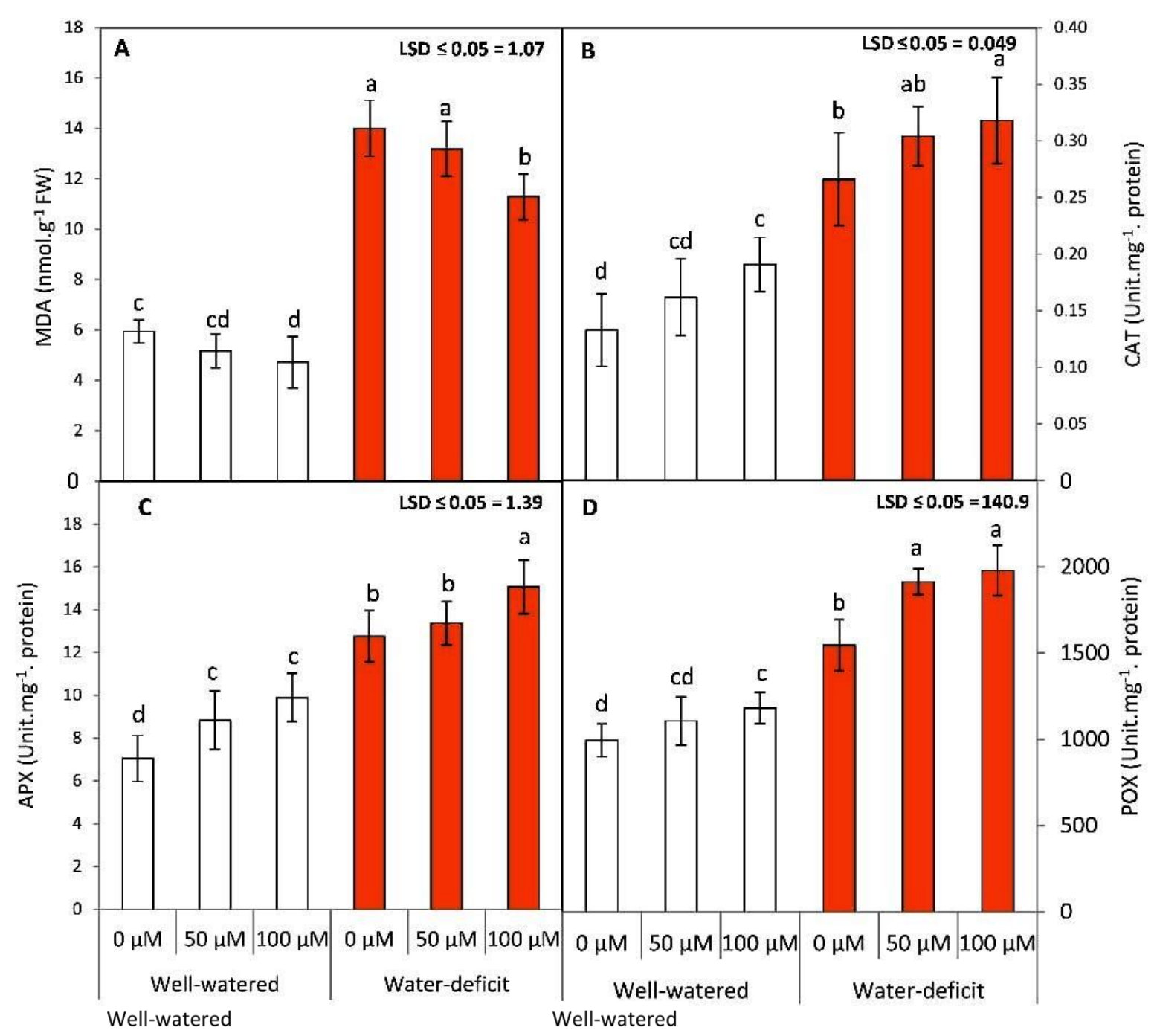

Figure 4. Effects of SNP as foliar applications at 0,50 , and $100 \mu \mathrm{M}$ on malondialdehyde (A), catalase (B), ascorbate peroxidase (C), peroxidase, and (D) guaiacol peroxidase of tomato plants grown under well-watered and water deficit irrigation. Data followed by the same letters are not significantly different using the LSD multiple rang test at a $5 \%$ level. 


\subsection{Correlations Among Osmolytes, Antioxidant Enzyme Activity, and RWC}

The regression analysis revealed that the osmolyte content (proline and soluble sugars) and antioxidant enzyme activity (CAT, APX, and POD) exhibited an inverse correlation with the increase in RWC under both irrigation regimes (Figure 5A-F). Thus, the reduction in RWC due to osmotic stress was significantly correlated with an increase in osmolyte content and elevation in antioxidant enzymes' activity during WD stress.

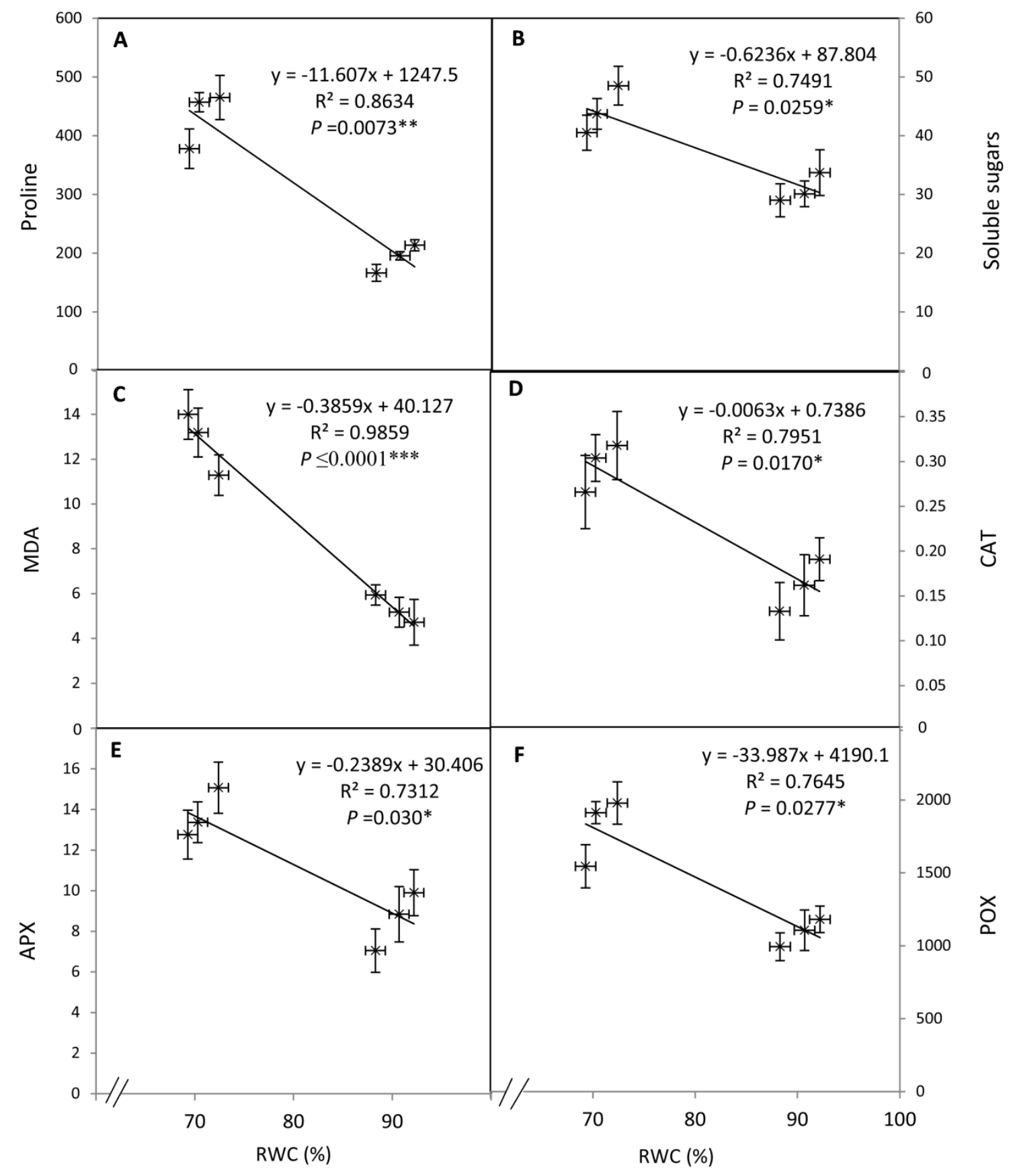

Figure 5. Relationships between osmolytes (proline and total soluble sugars), lipid peroxidation, antioxidant enzymes (CAT, APX, and POX), and RWC in the leaves of tomato plants as affected by SNP as foliar applications at 0, 50, and 100 $\mu \mathrm{M}$ under well-watered and water deficit irrigation regimes. NS: nonsignificant. ${ }^{*} p \leq 0.05 ;{ }^{* *} p \leq 0.01 ;{ }^{* * *} p \leq 0.001$. 


\subsection{Exogenous SNP Modulates Viral Disease Incidence and Severity Index in the Absence and Presence of Water Stress}

The viral disease incidence (natural) of tomato plants was evaluated in the field at different growth stages $(4,6,8$, and 10 WAT). Deficit irrigation significantly $(p \leq 0.05)$ decreased the viral disease incidence (natural) at different growth stages in the field when compared to under the well-irrigated conditions in both seasons (Figure 6). However, the rate of viral disease incidence on tomato plants was increased along with the advancement in plant growth. Generally, exogenous SNP significantly diminished the percentage of viral disease incidence on tomato plants at all studied growth stages compared to under the untreated plants in both seasons. In this context, the treatment of $100 \mu \mathrm{M}$ SNP achieved a lower value of viral disease incidence (\%) compared to $50 \mu \mathrm{M} \mathrm{SNP}$ at all the growth stages in both seasons. All possible interactive treatments revealed that the treatment of SNP at $100 \mu \mathrm{M}$ followed by $50 \mu \mathrm{M}$ achieved the lowest values at 4 WAT.

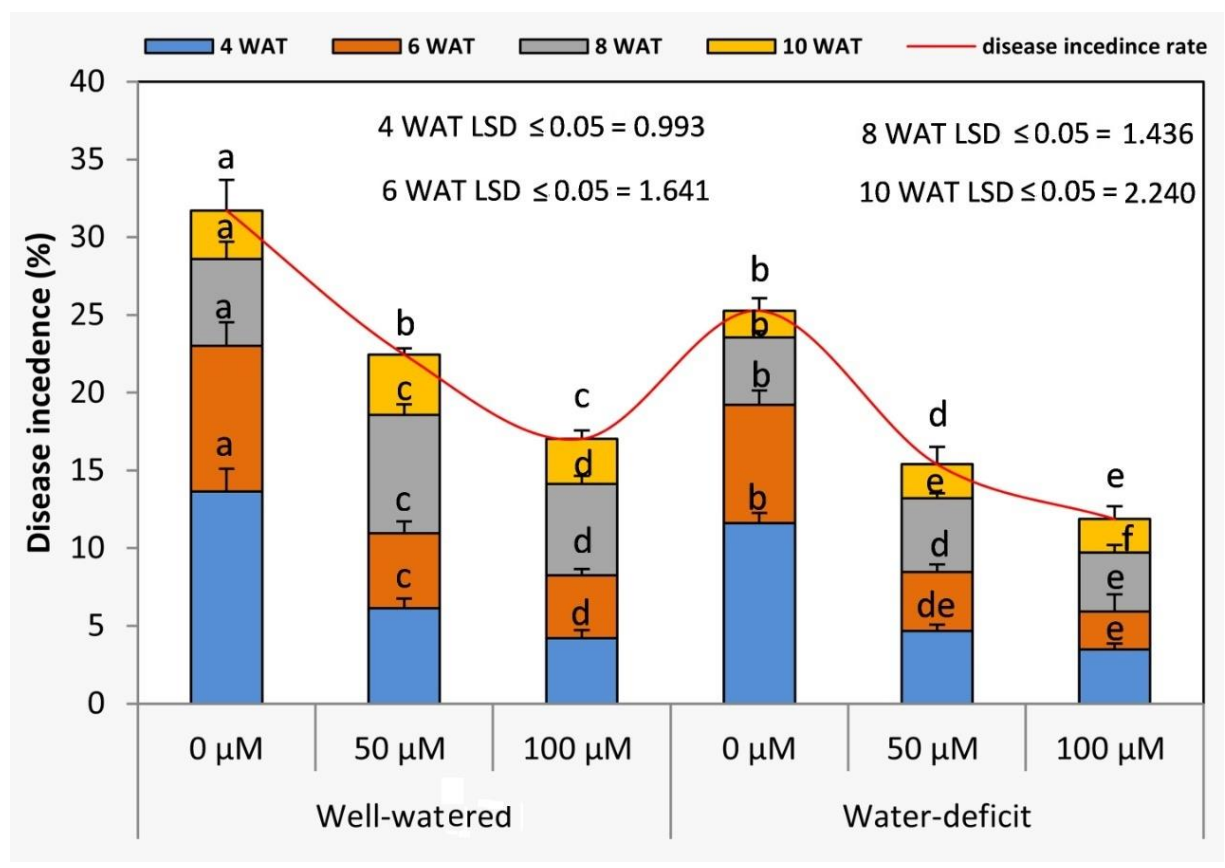

Figure 6. Effects of SNP as foliar applications at 0,50 , and $100 \mu \mathrm{M}$ on viral disease incidence of tomato plants. In each variable, data followed by the same letters are not significantly different using the LSD multiple rang test at a 5\% level. WAT: weeks after transplanting.

Under the water stress conditions, the viral disease severity indices of tomato plants were significantly $(p \leq 0.05)$ decreased at different growth stages $(4,6,8$, and 10 WAT) when compared to those of the well-irrigated plants in both seasons (Figure 7). The results indicated that the increase in viral disease severity index coincided with the rise in the age of plants. Generally, the treatment of SNP at $100 \mu \mathrm{M}$ resulted in lower rates of viral disease severity index compared to those of the untreated plants at different growth stages in both seasons. 


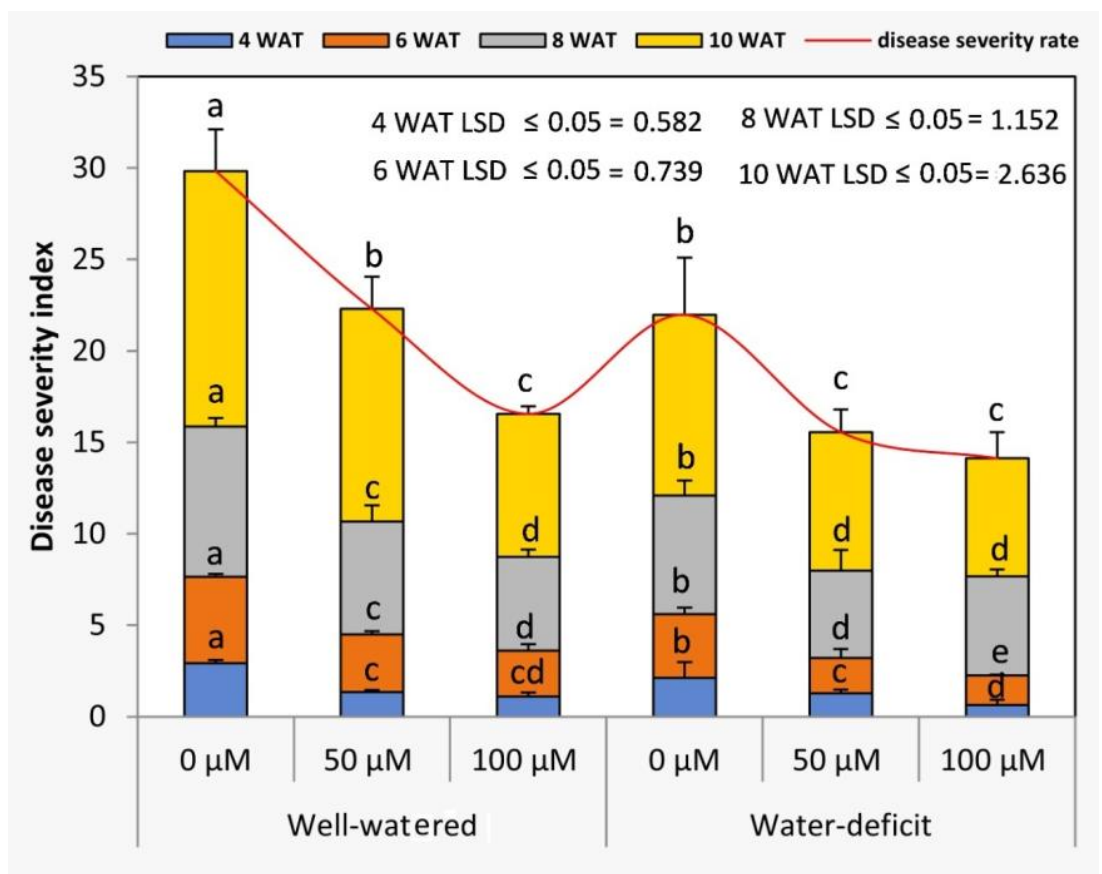

Figure 7. Effects of SNP as foliar applications at 0,50 , and $100 \mu \mathrm{M}$ on the viral disease severity index of tomato plants. In each variable, data followed by the same letters are not significantly different using the LSD multiple rang test at a 5\% level. WAT: weeks after transplanting.

\subsection{Exogenous SNP Application Reduces the Relative Concentrations of TMV and TYLCV}

The foliar applications of SNP significantly $(p \leq 0.05)$ diminished the relative concentrations of TMV and TYLCV at 10 WAT compared to in the untreated plants in both seasons (Figure 8). In general, the lowest values of TMV and TYLCV concentrations at 10 WAT were obtained by the treatment of $100 \mu \mathrm{M}$ SNP under the water stress conditions in both seasons. Furthermore, the relative concentration of TYLCV was reduced in the presence of water stress in tomato plants.

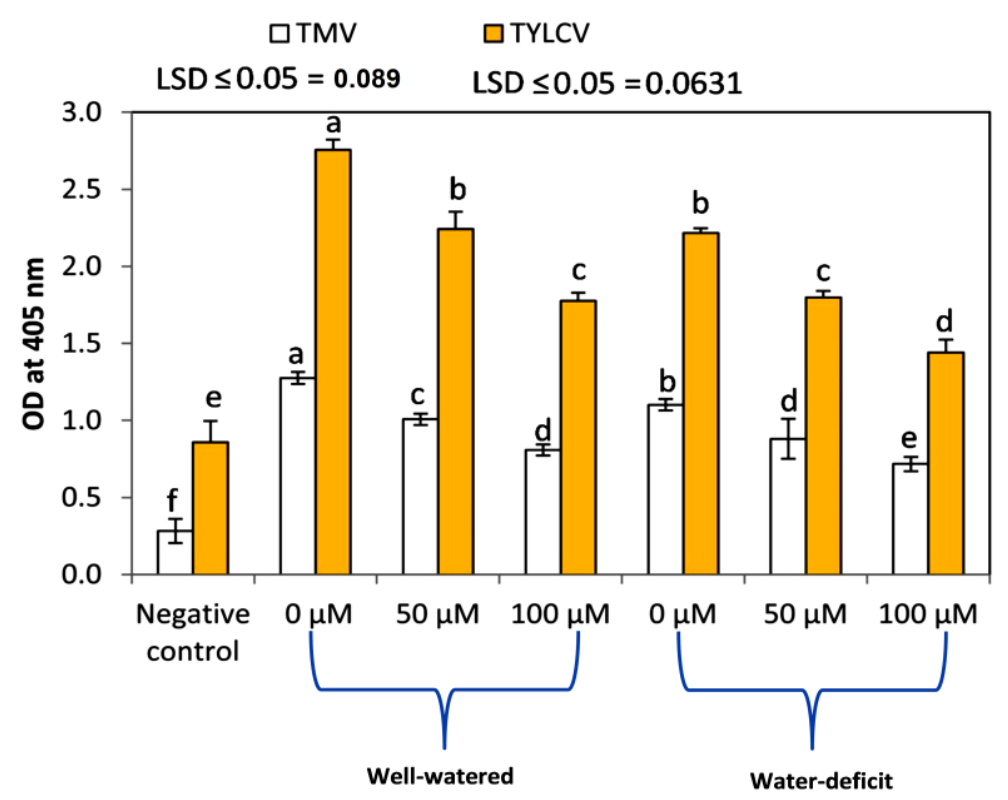

Figure 8. Effects of SNP as a foliar application on the relative concentrations of TMV and TYLCV using the ELISA technique on tomato plants grown under two different irrigation regimes at 10 WAT. Data followed by the same letters are not significantly different using the LSD multiple rang test at a $5 \%$ level. 


\subsection{Effect of Exogenous SNP on the Relative Concentration of TMV with the Biological Method}

The average number of local lesions of TMV was evaluated biologically in the second season (Figure 9). The cell sap of the infected tomato plants in the field from SNP treatments under both levels of irrigation was taken as a source of infection on N. glutinosa in a greenhouse under controlled conditions. After seven days from inoculation, the number of local lesions appeared higher as a result of the inoculation with the cell sap of the WW than that in those under the WD conditions. Furthermore, the foliar application of $100 \mu \mathrm{M}$ SNP demonstrated a decrease in the number of local lesions. These results indicated that $\mathrm{NO}$ at an appropriate concentration might likely reinforce the tolerance of tomato plants to viral diseases.
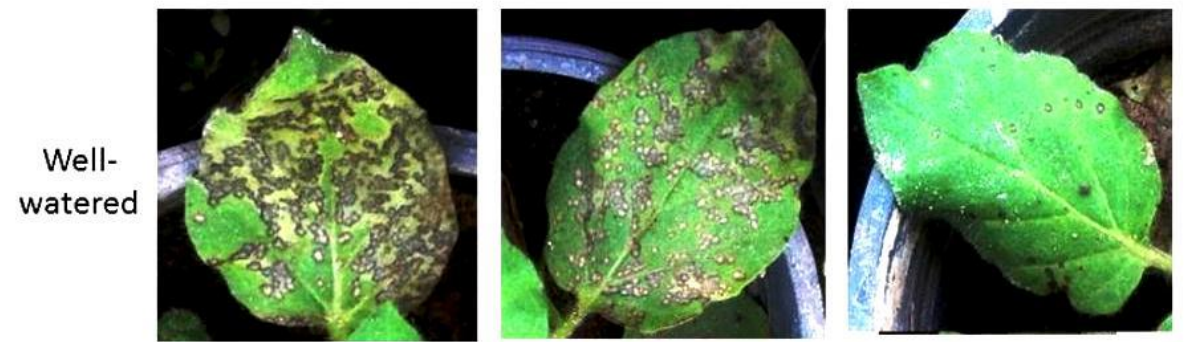

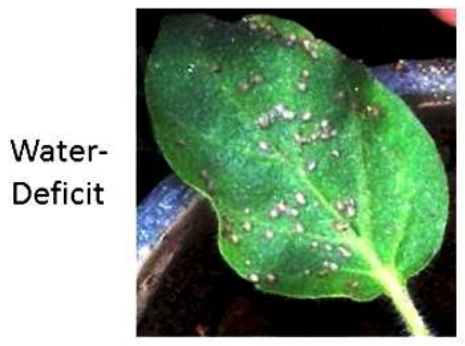

$0 \mu \mathrm{M}$

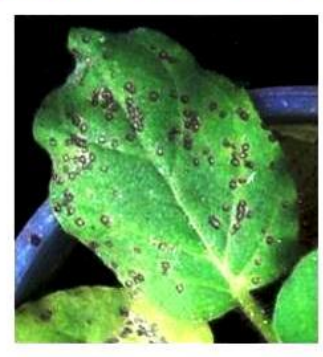

$50 \mu \mathrm{M}$

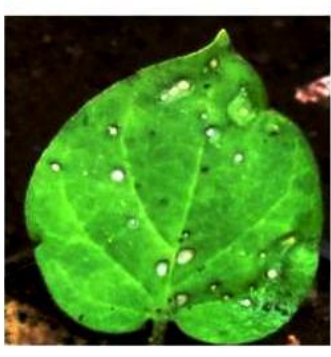

$100 \mu \mathrm{M}$

Figure 9. Biological estimation demonstrates the effect of SNP as a foliar application on the relative concentration of TMV isolated from naturally infected tomato plants grown in the field under two irrigation regimes in the second season. The higher number of local lesions on the viral plant detector (Nicotiana glutinosa) indicates a higher relative concentration of virus particles in the infected tomato plants.

\section{Discussion}

WD may trigger a broad spectrum of deleterious effects that can restrict plant growth and development, including inhibition of cell division [7], photosynthesis [8], and disequilibrium of plant growth regulators [9]. Furthermore, WD can induce oxidative damages [12] that may affect leaf pigments, cell membrane integrity, and leaf water status. In this study, water deficiency seriously reduced the growth parameters, chlorophyll, and RWC compared to those of the well-irrigated plants in both seasons.

In the present work, the foliar application of SNP up to $100 \mu \mathrm{M}$ as a donor to NO positively affected several developmental, physiological, and biochemical aspects of tomato plants under water nonstress and stress conditions. This trend was partially reversed, when the plants were subjected to the treatment of $150 \mu \mathrm{M}$. Although NO is a key signaling molecule that may be involved in various vital processes of plants, it can act as a major element of RNS, which leads to nitrosative stress [13].

Under water shortage or osmotic stress conditions, the exogenously applied NO donor (SNP) has been found to enhance the growth of many plant species, i.e., tomato [36], barley [37], and wheat [38]. Nitric oxide (NO) is considered a gaseous phytohormone that is involved in a wide array of developmental and physiological processes. It has been evidenced to enhance growth, chlorophyll, RWC, photosynthesis, and antioxidant capacity of tomato plants [17]. Moreover, it has an essential role in signaling and plant responses 
to diverse biotic and abiotic stresses [14]. In addition, nitric oxide is implicated in the development of adventitious roots through mediating the indole acetic acid induction and activating a mitogen-activated protein kinase [15]. In the present work, these effects may relatively interpret the efficient uptake of water and improve the growth, chlorophyll, and RWC under both adequate and water stress conditions.

In this study, when plants were exposed to deficit irrigation, oxidative damage from the excessive releasing of ROS may occur and consequently increase the level of membrane lipid peroxidation as indicated by the higher estimated MDA compared to that of the well-irrigated plants in both seasons. This response is consistent with many previous studies $[39,40]$. Proline and soluble sugars are two major compatible solutes in the defense mechanisms that keep the osmotic potential and the intracellular redox status at homeostasis under water stress conditions [41,42]. Phenolic compounds are also potent reducing agents with antioxidant properties that represent an essential source for carbon and maintain the redox status under water stress conditions [43,44].

In the present investigation, applied SNP suppressed MDA and enhanced proline, soluble sugars, and phenols. Two of the most important functions of NO in the plants are the alleviation of oxidative damage by reinforcing its antioxidative system [18] and upregulating the osmolyte metabolism [45]. Exogenous NO can maintain a high proline content by increasing the activities and transcript level of $\Delta^{1}$-pyrroline-5-carboxylate synthase (P5CS), the major enzyme in proline synthesis [46]. Furthermore, nitric oxide can affect soluble sugars through its role in regulating photosynthesis $[17,38]$. In addition, phenolic compounds are considered nonenzymatic antioxidants that may be induced by exogenous NO [47].

The activities of four antioxidant enzymes (APX, CAT, POX, and PPO) were hardly affected under the WW conditions. At the same time, these enzymes exhibited higher activities under the water stress conditions in both seasons. These results implied that under stress conditions, tomato plants have evolved several effective enzymatic antioxidative defense systems that may maintain ROS under controlled levels [5]. It has been found that different enzymatic antioxidative systems can be boosted by exogenously applied SNP [48]. Under osmotic stress associated with drought or salinity, SNP treatment was demonstrated to enhance the activity of APX in tomato plants [36]. This enzyme (APX) is capable of preventing the excessive accumulation of $\mathrm{H}_{2} \mathrm{O}_{2}$ in the plant cells through the ascorbate-glutathione cycle [49]. Furthermore, it has been reported that the activities of CAT and POX were positively affected by tomato plants by exogenously applied SNP [17]. Both enzymes are also responsible for the scavenging of $\mathrm{H}_{2} \mathrm{O}_{2}$ by different strategies; CAT can directly catalyst the conversion of $\mathrm{H}_{2} \mathrm{O}_{2}$ into water and $\mathrm{O}_{2}$ without the need for cellular reductants [50]. However, the presence of phenolic or indolic compounds as cellular reductants is essential for the activity of POX [51]. These results may interpret the improvement of the examined antioxidant enzymes (APX, CAT, and POX) with SNP applications under water stress conditions in this study.

The yield is always regarded as the final result of the plant's performance throughout the season. In the present study, it has been proved that WD inhibited plant growth, chlorophyll, and RWC. Besides, it induced leaf tissue oxidative damage and altered several biochemical constituents and activities of antioxidative systems. Furthermore, under water shortage, the photosynthetic apparatus could be exposed to oxidative damage, limiting $\mathrm{CO}_{2}$ assimilation and stomatal conductance [52]. All of these responses could interpret the dramatic decline of the fruit yield in this study. However, applied NO exhibited a noticeable improvement in plant growth and relatively reversed most of the negative effects of WD, which eventually reflected the yield. These results are in harmony with those obtained by Jangid and Dwivedi [20].

Lycopene acts as an antioxidant with a particular environmental defence mechanism by scavenging peroxyl radicals and quenching singlet oxygen. Previous reports found that in tomato, lycopene in fruits increased under drought to mitigate the harmful effect of the stress [16]. In this study, the increase in the lycopene content under water stress 
could be attributed to decreasing the fruit content of water, as known by the concentration effect. Conversely, the exogenous application of SNP was shown to retard the fruit maturity partially and reduce the lycopene content. Nitric oxide (NO) is involved in the delay of the ripening of both climacteric and nonclimacteric fruits [16]. It has been found that the rate of respiration is suppressed, flesh softening enzymes are reduced and the ripening, the climacteric phase, disease incidence, and development of browning disorders in fruits are delayed by countering the ethylene effect [53-55]. The inhibiting effect of NO on the biosynthesis of ethylene may be attributed to the genetic suppression of the ethylene biosynthesis enzymes: ACC synthase and ACC oxidase [56].

In nature, nitric oxide (NO), nitrite $\left(\mathrm{NO}_{2}\right)$, and nitrate $\left(\mathrm{NO}_{3}\right)$ are considered fundamental components of the nitrogen cycle, which may be converted to each other by biological oxidoreductive steps [57]. Accumulation of nitrite and/or nitrate in the edible parts of plants is considered hazardous and may pose a threat to public health. Therefore, in this study, we examined the effect of NO application on the contents of nitrite and nitrate in the tomato fruits. Our results indicated that there was a dearth or absence of nitrite with all SNP treatments under both levels of irrigation. Nitrite $\left(\mathrm{NO}_{2}\right)$ is an unstable molecule, which is rapidly converted into $\mathrm{NO}$ by nitrate reductase (NR) [57]. Additionally, water stress decreased $\mathrm{NO}_{3}$ compared to that of the well-irrigated plants in both seasons. This effect could be due to the decreases in the concentration or activities of the major $\mathrm{N}$-uptake proteins (NRT1 and NRT2), which are responsible for the uptake of inorganic nitrate $\left(\mathrm{NO}_{3}\right)$ [58]. However, it has been evidenced that part of the $\mathrm{NO}$ produced by the L-arginine-dependent pathway could be oxidized to $\mathrm{NO}_{2}$ and consequently to $\mathrm{NO}_{3}$ [57]. In this study, this response may explain the increase of $\mathrm{NO}_{3}$ by the exogenous applications of SNP. However, this increase is fully safe in human feeding, because the World Health Organization (WHO) recommended that the maximum limit of the daily concentrations of nitrite and nitrate uptake should be $0.06-0.07$ and $3.7 \mathrm{mg} \mathrm{kg}^{-1}$, respectively [59].

In the present investigation, viral disease incidence, disease severity index, and the relative concentrations of TMV and TYLCV were significantly decreased from the serological and biological points of view under water stress conditions in both seasons. This could be attributed to decrease in hypersensitivity and redox balance maintained by the elevation in the activity of different antioxidant enzymes (present work). Nitric oxide (NO) is considered an important signaling and regulatory molecule in plant defense against biotic stresses $[60,61]$. In the present work, nitric oxide likely reduced viral infection and its severity compared to for the untreated plants. These results could probably be attributed to the direct effect of NO on increasing the accumulation of SA, which further triggered the activation of $P R$ gene expression ( $P R 1$ and $P R 5)$, thus imparting resistance to viral diseases [19]. Although persuasive at present, future investigations are likely to reveal the mechanisms of NO-mediated alleviation of biotic stress induced by TMV and TYLCV. Although not much information is available on the role of $\mathrm{NO}$ in the regulation of viral diseases in plants, certain earlier investigations reveal the association of NO with the viral disease in Hibiscus cannabinus L., Oryza sativa, and Zea mays [62-64]. Considering the changes in the activity of phenylalanine ammonia-lyase (PAL) as a marker, Sarkar et al. (2010) observed a surge in the NO levels in Hibiscus cannabinus L. plants infected with a begomovirus. Furthermore, increased NO and RNS levels were associated with increased tyrosine nitration of proteins.

Interestingly, in congruence to our present observations, exogenous nitric oxide (SNP) has been known to reduce disease incidence for rice black-streaked dwarf virus (RBSDV) in rice plants [63]. The increased amount of tyrosine nitration of proteins was attributed to NO-induced defense at the post-translational level [63]. Cao, et al. [62] has extended our understanding of NO-induced disease resistance for maize chlorotic mottle virus to be regulated by the activity of brassinosteroids. Similar to earlier evidences, our present findings revealed the beneficial role of $\mathrm{NO}$ in imparting viral disease resistance to tomato plants. Furthermore, nitric oxide application appeared to be more effective in reducing disease incidence and severity in the early stages of plant growth (4 WAT). WD reduced 
the percentage of disease incidence for both $T M V$ and TYLCV, thus suggesting the role of irrigation in regulating disease occurrence. To sum up, the present work provides insights into the beneficial role of exogenous SNP (NO donor) in mitigating drought stress, improving yield attributes and reducing viral disease infection in tomato plants.

\section{Conclusions}

Although certain reports reveal the toxicity effects of SNP-mediated cyanide $\left(\mathrm{CN}^{-}\right)$ generation, sodium nitroprusside application bears agronomic importance in NO-mediated tolerance to biotic and abiotic stress in plants. In this study, we investigated the effect of the foliar application of $\mathrm{NO}$ on tomato plants grown under two irrigation regimes. Generally, under water stress conditions, plant growth, chlorophyll, RWC, fruit yield, and its contents of nitrite and nitrate were decreased, while MDA, proline, soluble sugars, soluble phenols, activities of antioxidant enzymes (APX, CAT, POX, and PPO), and lycopene were increased. The $100 \mu \mathrm{M}$ SNP application relatively mitigated all the deleterious effects of water stress. The treatment of $100 \mu \mathrm{M}$ SNP could be recommended to alleviate the injurious effects of water stress and reduce the natural viral disease incidence.

Author Contributions: Conceptualization M.F.M.I., H.A., A.B., and H.G.A.E.-G.; methodology, A.E., M.F.M.I., H.A., A.B., A.A.E.-Y., E.A., and H.G.A.E.-G.; software, M.F.M.I., S.M., T.A., M.H., A.A.E.-Y., E.A., and H.G.A.E.-G.; validation, A.E., T.A., M.H., A.A.E.-Y., E.A., A.A.M., A.A.G., M.M.-F., and H.G.A.E.-G.; formal analysis, M.F.M.I., A.B., S.M., and H.G.A.E.-G.; investigation, A.E., M.F.M.I., M.H., A.A.E.-Y., E.A., and H.G.A.E.-G.; resources, A.E., M.F.M.I., H.A., A.B., E.A., and H.G.A.E.-G.; data curation, M.F.M.I., H.A., A.B., S.M., and H.G.A.E.-G.; writing of the original draft preparation, A.E., M.F.M.I., H.A., A.B., S.M., and H.G.A.E.-G.; writing of review and editing, A.E., M.F.M.I, A.A.M., A.A.G., M.M.-F., H.A., A.B., S.M., T.A., M.H., A.A.E.-Y., E.A., A.A.M., and H.G.A.E.-G.; supervision, A.E., M.F.M.I., and H.G.A.E.-G.; project administration, A.E., M.F.M.I., A.A.M., A.A.G., M.M.-F., H.A., and H.G.A.E.-G.; funding acquisition, A.E., M.F.M.I., E.A., A.A.G., M.M.-F., and H.G.A.E.-G. All authors have read and agreed to the published version of the manuscript.

Funding: This research received no external funding.

Institutional Review Board Statement: Not applicable.

Informed Consent Statement: Not applicable.

Data Availability Statement: Not applicable.

Acknowledgments: We thank the researchers in Taif University, Taif, Saudi Arabia (supporting project number: TURSP-2020/13).

Conflicts of Interest: The authors declare no conflict of interest.

\section{References}

1. Habib, N.; Ali, Q.; Ali, S.; Javed, M.T.; Zulqurnain Haider, M.; Perveen, R.; Shahid, M.R.; Rizwan, M.; Abdel-Daim, M.M.; Elkelish, A.; et al. Use of Nitric Oxide and Hydrogen Peroxide for Better Yield of Wheat (Triticum aestivum L.) under Water Deficit Conditions: Growth, Osmoregulation, and Antioxidative Defense Mechanism. Plants 2020, 9, 285. [CrossRef] [PubMed]

2. Soliman, M.; Elkelish, A.; Souad, T.; Alhaithloul, H.; Farooq, M. Brassinosteroid Seed Priming with Nitrogen Supplementation Improves Salt Tolerance in Soybean. Physiol. Mol. Biol. Plants 2020. [CrossRef] [PubMed]

3. Zamin, M.; Fahad, S.; Khattak, A.M.; Adnan, M.; Wahid, F.; Raza, A.; Wang, D.; Saud, S.; Noor, M.; Bakhat, H.F.; et al. Developing the First Halophytic Turfgrasses for the Urban Landscape from Native Arabian Desert Grass. Environ. Sci. Pollut. Res. 2020, 27, 39702-39716. [CrossRef] [PubMed]

4. Soliman, M.H.; Abdulmajeed, A.M.; Alhaithloul, H.; Alharbi, B.M.; El-Esawi, M.A.; Hasanuzzaman, M.; Elkelish, A. Saponin Biopriming Positively Stimulates Antioxidants Defense, Osmolytes Metabolism and Ionic Status to Confer Salt Stress Tolerance in Soybean. Acta Physiol. Plant 2020, 42, 114. [CrossRef]

5. Ibrahim, M.F.M.; Bondok, A.M.; Al-Senosy, N.K.; Younis, R.A. Stimulation Some of Defense Mechanisms in Tomato Plants under Water Deficit and Tobacco mosaic virus (TMV). World J. Agric. Sci. 2015, 11, 289-302.

6. Tajul, M.; Naher, K.; Hossain, T.; Siddiqui, Y.; Sariah, M. Tomato yellow leaf curl virus (TYLCV) alters the phytochemical constituents in tomato fruits. Aust. J. Crop Sci. 2011, 5, 575.

7. Hashim, A.M.; Alharbi, B.M.; Abdulmajeed, A.M.; Elkelish, A.; Hozzein, W.N.; Hassan, H.M. Oxidative Stress Responses of Some Endemic Plants to High Altitudes by Intensifying Antioxidants and Secondary Metabolites Content. Plants 2020, 9, 869. [CrossRef] 
8. Saied, E.M.; Arenz, C. Inhibitors of Ceramidases. Chem. Phys. Lipids 2016, 197, 60-68. [CrossRef]

9. Saied, E.M.; Arenz, C. Small Molecule Inhibitors of Ceramidases. CPB 2014, 34, 197-212. [CrossRef]

10. Huang, G.-T.; Ma, S.-L.; Bai, L.-P.; Zhang, L.; Ma, H.; Jia, P.; Liu, J.; Zhong, M.; Guo, Z.-F. Signal transduction during cold, salt, and drought stresses in plants. Mol. Biol. Rep. 2012, 39, 969-987. [CrossRef]

11. Poad, B.L.J.; Maccarone, A.T.; Yu, H.; Mitchell, T.W.; Saied, E.M.; Arenz, C.; Hornemann, T.; Bull, J.N.; Bieske, E.J.; Blanksby, S.J. Differential-Mobility Spectrometry of 1-Deoxysphingosine Isomers: New Insights into the Gas Phase Structures of Ionized Lipids. Anal. Chem. 2018, 90, 5343-5351. [CrossRef]

12. Ahmad, P.; Jamsheed, S.; Hameed, A.; Rasool, S.; Sharma, I.; Azooz, M.; Hasanuzzaman, M. Drought stress induced oxidative damage and antioxidants in plants. In Oxidative Damage to Plants; Elsevier: Amsterdam, The Netherlands, 2014 ; pp. 345-367. [CrossRef]

13. Corpas, F.J.; Leterrier, M.; Valderrama, R.; Airaki, M.; Chaki, M.; Palma, J.M.; Barroso, J.B. Nitric oxide imbalance provokes a nitrosative response in plants under abiotic stress. Plant Sci. 2011, 181, 604-611. [CrossRef] [PubMed]

14. Corpas, F.J.; Palma, J.M. Assessing nitric oxide (NO) in higher plants: An outline. Nitrogen 2018, 1, 12-20. [CrossRef]

15. Pagnussat, G.C.; Lanteri, M.L.; Lombardo, M.C.; Lamattina, L. Nitric oxide mediates the indole acetic acid induction activation of a mitogen-activated protein kinase cascade involved in adventitious root development. Plant Physiol. 2004, 135, 279-286. [CrossRef]

16. Bodanapu, R.; Gupta, S.K.; Basha, P.O.; Sakthivel, K.; Sreelakshmi, Y.; Sharma, R. Nitric oxide overproduction in tomato shr mutant shifts metabolic profiles and suppresses fruit growth and ripening. Front. Plant Sci. 2016, 7, 1714. [CrossRef] [PubMed]

17. Hayat, S.; Yadav, S.; Wani, A.S.; Irfan, M.; Ahmad, A. Nitric oxide effects on photosynthetic rate, growth, and antioxidant activity in tomato. Int. J. Veg. Sci. 2011, 17, 333-348. [CrossRef]

18. Zhang, Y.; Han, X.; Chen, X.; Jin, H.; Cui, X. Exogenous nitric oxide on antioxidative system and ATPase activities from tomato seedlings under copper stress. Sci. Hortic. 2009, 123, 217-223. [CrossRef]

19. Klessig, D.F.; Durner, J.; Noad, R.; Navarre, D.A.; Wendehenne, D.; Kumar, D.; Zhou, J.M.; Shah, J.; Zhang, S.; Kachroo, P. Nitric oxide and salicylic acid signaling in plant defense. Proc. Natl. Acad. Sci. USA 2000, 97, 8849-8855. [CrossRef]

20. Jangid, K.K.; Dwivedi, P. Physiological and biochemical changes by nitric oxide and brassinosteroid in tomato (Lycopersicon esculentum Mill.) under drought stress. Acta Physiol. Plant. 2017, 39, 73. [CrossRef]

21. Hajivar, B.; Zare-Bavani, M.R. Alleviation of salinity stress by hydrogen peroxide and nitric oxide in tomato plants. Adv. Hortic. Sci. 2019, 33. [CrossRef]

22. Arnon, D.I. Copper enzymes in isolated chloroplasts. Polyphenoloxidase in Beta vulgaris. Plant Physiol. 1949, 24, 1-15. [CrossRef] [PubMed]

23. Ünyayar, S.; Kelep, Y.; Ünal, E. Proline and ABA levels in two sunflower genotypes subjected to water stress. Proc. Bulg. J. Plant Physiol. 2004, 30, 34-47.

24. Heath, R.L.; Packer, L. Photoperoxidation in isolated chloroplasts: I. Kinetics and stoichiometry of fatty acid peroxidation. Arch Biochem. Biophys. 1968, 125, 189-198. [CrossRef]

25. Bates, L.; Waldren, R.; Teare, I. Rapid determination of free proline for water-stress studies. Plant Soil 1973, 39, 205-207. [CrossRef]

26. Chow, P.S.; Landhäusser, S.M. A method for routine measurements of total sugar and starch content in woody plant tissues. Tree Physiol. 2004, 24, 1129-1136. [CrossRef]

27. Bradford, M.M. A rapid and sensitive method for the quantitation of microgram quantities of protein utilizing the principle of protein-dye binding. Anal. Biochem. 1976, 72, 248-254. [CrossRef]

28. Nakano, Y.; Asada, K. Hydrogen peroxide is scavenged by ascorbate-specific peroxidase in spinach chloroplasts. Plant Cell Physiol. 1981, 22, 867-880. [CrossRef]

29. Cakmak, I.; Strbac, D.; Marschner, H. Activities of hydrogen peroxide-scavenging enzymes in germinating wheat seeds. J. Exp. Bot. 1993, 44, 127-132. [CrossRef]

30. Hammerschmidt, R.; Nuckles, E.; Kuć, J. Association of enhanced peroxidase activity with induced systemic resistance of cucumber to Colletotrichum lagenarium. Physiol. Plant Pathol. 1982, 20, 73-82. [CrossRef]

31. Nelson, M.R.; Orum, T.V.; Jaime-Garcia, R.; Nadeem, A. Applications of geographic information systems and geostatistics in plant disease epidemiology and management. Plant Dis. 1999, 83, 308-319. [CrossRef]

32. Clark, M.F.; Adams, A. Characteristics of the microplate method of enzyme-linked immunosorbent assay for the detection of plant viruses. J. Gen. Virol. 1977, 34, 475-483. [CrossRef] [PubMed]

33. Fish, W.W.; Perkins-Veazie, P.; Collins, J.K. A quantitative assay for lycopene that utilizes reduced volumes of organic solvents. J. Food Compos. Anal. 2002, 15, 309-317. [CrossRef]

34. Sen, N.P.; Donaldson, B. Improved colorimetric method for determining nitrate and nitrite in foods. J. Assoc. Off. Anal. Chem. 1978, 61, 1389-1394. [CrossRef] [PubMed]

35. SAS. SAS/STAT User's Guide: Release 6.03 ed; SAS Institute Inc.: Cary, NC, USA, 1988.

36. Nasibi, F.; Kalantari, K.M. Influence of nitric oxide in protection of tomato seedling against oxidative stress induced by osmotic stress. Acta Physiol. Plant. 2009, 31, 1037-1044. [CrossRef]

37. Gan, L.; Wu, X.; Zhong, Y. Exogenously Applied Nitric Oxide Enhances the Drought Tolerance in Hulless Barley. Plant Prod. Sci. 2015, 18, 52-56. [CrossRef] 
38. Faraji, J.; Sepehri, A. Exogenous Nitric Oxide Improves the Protective Effects of $\mathrm{TiO}_{2}$ Nanoparticles on Growth, Antioxidant System, and Photosynthetic Performance of Wheat Seedlings Under Drought Stress. J. Soil Sci. Plant Nutr. 2020, 1-12. [CrossRef]

39. Liu, J.; Wang, W.; Wang, L.; Sun, Y. Exogenous melatonin improves seedling health index and drought tolerance in tomato. Plant Growth Regul. 2015, 77, 317-326. [CrossRef]

40. Zhu, M.; Meng, X.; Cai, J.; Li, G.; Dong, T.; Li, Z. Basic leucine zipper transcription factor SlbZIP1 mediates salt and drought stress tolerance in tomato. BMC Plant Biol. 2018, 18, 83. [CrossRef]

41. Chołuj, D.; Karwowska, R.; Ciszewska, A.; Jasińska, M. Influence of long-term drought stress on osmolyte accumulation in sugar beet (Beta vulgaris L.) plants. Acta Physiol. Plant. 2008, 30, 679. [CrossRef]

42. Per, T.S.; Khan, N.A.; Reddy, P.S.; Masood, A.; Hasanuzzaman, M.; Khan, M.I.R.; Anjum, N.A. Approaches in modulating proline metabolism in plants for salt and drought stress tolerance: Phytohormones, mineral nutrients and transgenics. Plant Physiol. Biochem. 2017, 115, 126-140. [CrossRef]

43. Varela, M.C.; Arslan, I.; Reginato, M.A.; Cenzano, A.M.; Luna, M.V. Phenolic compounds as indicators of drought resistance in shrubs from Patagonian shrublands (Argentina). Plant Physiol. Biochem. 2016, 104, 81-91. [CrossRef]

44. Weidner, S.; Karolak, M.; Karamac, M.; Kosinska, A.; Amarowicz, R. Phenolic compounds and properties of antioxidants in grapevine roots [Vitis vinifera L.] under drought stress followed by recovery. Acta Soc. Bot. Pol. 2009, 78, 97-103. [CrossRef]

45. Soliman, M.; Alhaithloul, H.A.; Hakeem, K.R.; Alharbi, B.M.; El-Esawi, M.; Elkelish, A. Exogenous Nitric Oxide Mitigates Nickel-Induced Oxidative Damage in Eggplant by Upregulating Antioxidants, Osmolyte Metabolism, and Glyoxalase Systems. Plants 2019, 8, 562. [CrossRef] [PubMed]

46. Ruan, H.-H.; Shen, W.-B.; Xu, L.-L. Nitric oxide involved in the abscisic acid induced proline accumulation in wheat seedling leaves under salt stress. Acta Bot. Sin. Engl. Ed. 2004, 46, 1307-1315.

47. Duan, X.; Su, X.; You, Y.; Qu, H.; Li, Y.; Jiang, Y. Effect of nitric oxide on pericarp browning of harvested longan fruit in relation to phenolic metabolism. Food Chem. 2007, 104, 571-576. [CrossRef]

48. Wang, Q.; Liang, X.; Dong, Y.; Xu, L.; Zhang, X.; Hou, J.; Fan, Z. Effects of exogenous nitric oxide on cadmium toxicity, element contents and antioxidative system in perennial ryegrass. Plant Growth Regul. 2013, 69, 11-20. [CrossRef]

49. Pang, C.-H.; Wang, B.-S. Role of ascorbate peroxidase and glutathione reductase in ascorbate-glutathione cycle and stress tolerance in plants. In Ascorbate-Glutathione Pathway and Stress Tolerance in Plants; Springer: New York, NY, USA, 2010; pp. 91-113. [CrossRef]

50. Mhamdi, A.; Queval, G.; Chaouch, S.; Vanderauwera, S.; Van Breusegem, F.; Noctor, G. Catalase function in plants: A focus on Arabidopsis mutants as stress-mimic models. J. Exp. Bot. 2010, 61, 4197-4220. [CrossRef]

51. Pandey, H.C.; Baig, M.; Chandra, A.; Bhatt, R. Drought stress induced changes in lipid peroxidation and antioxidant system in genus Avena. J. Environ. Biol. 2010, 31, 435-443.

52. Wang, Z.; Li, G.; Sun, H.; Ma, L.; Guo, Y.; Zhao, Z.; Gao, H.; Mei, L. Effects of drought stress on photosynthesis and photosynthetic electron transport chain in young apple tree leaves. Biol. Open 2018, 7, bio035279. [CrossRef]

53. Leshem, Y.a.Y.; Pinchasov, Y. Non-invasive photoacoustic spectroscopic determination of relative endogenous nitric oxide and ethylene content stoichiometry during the ripening of strawberries Fragaria anannasa (Duch.) and avocados Persea americana (Mill.). J. Exp. Bot. 2000, 51, 1471-1473. [CrossRef]

54. Manjunatha, G.; Gupta, K.J.; Lokesh, V.; Mur, L.A.; Neelwarne, B. Nitric oxide counters ethylene effects on ripening fruits. Plant Signal. Behav. 2012, 7, 476-483. [CrossRef] [PubMed]

55. Manjunatha, G.; Lokesh, V.; Neelwarne, B. Nitric oxide in fruit ripening: Trends and opportunities. Biotechnol. Adv. 2010, 28, 489-499. [CrossRef] [PubMed]

56. Eum, H.L.; Kim, H.B.; Choi, S.B.; Lee, S.K. Regulation of ethylene biosynthesis by nitric oxide in tomato (Solanum lycopersicum L.) fruit harvested at different ripening stages. Eur. Food Res. Technol. 2009, 228, 331. [CrossRef]

57. Galatro, A.; Puntarulo, S. An update to the understanding of nitric oxide metabolism in plants. In Nitric Oxide in Plants: Metabolism and Role in Stress Physiology; Springer: New York, NY, USA, 2014; pp. 3-15. [CrossRef]

58. Bista, D.R.; Heckathorn, S.A.; Jayawardena, D.M.; Mishra, S.; Boldt, J.K. Effects of drought on nutrient uptake and the levels of nutrient-uptake proteins in roots of drought-sensitive and-tolerant grasses. Plants 2018, 7, 28. [CrossRef]

59. Weitzberg, E.; Lundberg, J.O. Novel aspects of dietary nitrate and human health. Annu. Rev. Nutr. 2013, 33, 129-159. [CrossRef]

60. Sun, Z.-H.; Zhou, Y.-H.; Shi, K.; Li, X.; Zhang, G.-Q.; Xia, X.-J.; Chen, Z.-X.; Yu, J.-Q. The role of hydrogen peroxide and nitric oxisde in the induction of plant-encoded RNA-dependent RNA polymerase 1 in the basal defense against tobacco mosaic virus. PLOS ONE 2013, 8, e76090. [CrossRef]

61. Wendehenne, D.; Durner, J.; Klessig, D.F. Nitric oxide: A new player in plant signalling and defence responses. Curr. Opin. Plant Biol. 2004, 7, 449-455. [CrossRef]

62. Cao, N.; Zhan, B.; Zhou, X. Nitric Oxide as a Downstream Signaling Molecule in Brassinosteroid-Mediated Virus Susceptibility to Maize Chlorotic Mottle Virus in Maize. Viruses 2019, 11,368. [CrossRef]

63. Lu, R.; Liu, Z.; Shao, Y.; Su, J.; Li, X.; Sun, F.; Zhang, Y.; Li, S.; Zhang, Y.; Cui, J. Nitric Oxide Enhances Rice Resistance to Rice Black-Streaked Dwarf Virus Infection. Rice 2020, 13, 1-13. [CrossRef]

64. Sarkar, T.S.; Majumdar, U.; Roy, A.; Maiti, D.; Goswamy, A.M.; Bhattacharjee, A.; Ghosh, S.; Ghosh, S.K. Production of nitric oxide in host-virus interaction: A case study with a compatible begomovirus-kenaf host-pathosystem. Plant Signal. Behav. 2010, 5, 668-676. [CrossRef] 